\title{
Vágánygeometriai irány- és fekszinthibák valós nagyságának értékelése húrmérési eredmények alapján
}

\author{
A vasúti pálya méreteltéréseinek vizsgálata és a hibák megfelelö időben \\ történő elhárítása a biztonságos közlekedés feltétele. E cikk a vágány- \\ geometria ellenőrzése során alkalmazott eljárásokat tekinti át, és a húr- \\ mérések torzító hatásának kiküszöbölésével foglalkozik, illetve a loká- \\ lis hosszfekszint- és irányhibák értékelési problémáira keres megoldást.
}

DOI 10.24228/KTSZ.2018.5.4

\section{Ágh Csaba}

PhD-hallgató, Széchenyi István Egyetem

e-mail: csagh@mavkfv.hu

\section{BEVEZETÉS}

A vasúti pályák biztonságos és gazdaságos fenntartása össztársadalmi érdek. A biztonságos közlekedés szavatolásához a szakemberek felmérik a vágányban kifejlődő geometriai méreteltéréseket, és megakadályozzák a hibák balesetveszélyes mértékűvé növekedését. A gazdaságos üzemeltetés érdekében törekedni kell a pálya-jármű rendszerben zajló romlási folyamatok megértésére, ezek alapján a pálya aktuális vágánygeometriai állapotának helyes értékelésére és a pályasebességek szinten tartására. Az említett célok eléréséhez elengedhetetlen a vasúti pálya mindenkori, méreteltérésekkel és hibákkal terhelt valós alakjának pontos felvétele. A korszerü pályafenntartásban a rendszerdinamikai aspektusokat nélkülöző szemlélet elavultnak tekinthető [1], ezért a jövőben célszerü olyan módon is felhasználni a pálya geometriailag meghatározott paramétereit, hogy azok segítségével az egyes jármüvek, ill. a pálya-jármű rendszer dinamikai viselkedését modellezzük. Ahhoz, hogy a különböző járművek kisiklással szembeni biztonságát szimuláljuk egy adott vonalszakaszon, elengedhetetlen a valósnak tekinthetö, terhelés alatt létrejövő és torzításmentes pályaalak ismerete. Az utóbbi évtizedekben a számítástechnika, illetve a numerikus módszerek fejlődésével lehetővé vált a folyamatosan változó viszonyítási rendszerben (húrelven müködő mérőkocsival) felvett irány- és hosszfekszint-adatok gyors átszámítása abszolút viszonyítási rendszerbe, vagyis a torzításmentessé tétel. Mindamellett a hazai vasútvonalak nagy részén ma a hagyományos, torzításmentesítés nélküli húrmérési regisztrátum alapján zajlik a pályaállapot értékelése, illetve a pályafenntartási munka.

\section{A VÁGÁNYGEOMETRIA JELENTŐSÉGE}

A vasúti vágány pályatervezők által meghatározott milliméter pontosságú geometriáját a kivitelezők a hatályos előírásokban szereplő, számukra megengedett építési mérethetárokon belül néhány milliméteres hibákkal valósítják 


\section{Vasúti közlekedés}

meg. A vágányok függőleges és oldalirányú megtámasztását biztosító szerkezeti elemekben (ágyazat, kiegészítő rétegek, alépítmény) is elkerülhetetlen inhomogenitások lépnek fel. E kezdeti eltérések, illetve a közlekedő vonatokról pályára átadódó - maradó alakváltozást, illetve a szerkezeti anyagok fáradását okozó - erők, továbbá hőmérsékleti és egyéb hatások következtében a vágány terheletlen alakja tovább torzul, illetve a támasztó rétegek tömörségi viszonyai is szabálytalanabbá válnak. A vágány rugalmas deformációi (a sínszálakat leíró térgörbék időleges változásai) függnek a rajtuk éppen áthaladó jármüről átadódó erőktől is, amelyeket a járművek tömege, kialakítása, sebessége és parazita mozgásai (kígyózás, bólintás, támolygás, szitálás, rázás, rángatás) befolyásolnak. Ez utóbbiak létrejöttében éppen a vágány szabálytalanságai játszanak nagy szerepet. Ha a pálya-jármü rendszernek pusztán a pálya alrendszerét vizsgáljuk, akkor időben változó és matematikailag nehezen kezelhető térgörbékkel írhatjuk le a sínek vonatáthaladás közben felvett terhelés alatti alakját. Ez a nagyon rövid időre kialakuló alak azért fontos, mert kedvezőtlen esetben a vágánygeometriai eltérésekből adódóan kisiklás - vagy a pálya súlyos károsodása - következhet be. Minthogy a balesetveszély, illetve a vágánygeometria romlásának sebessége erősen függ az áthaladó vonatok sebességétől, a rossz vágánygeometriai minőségű szakaszokon sebességkorlátozásokat vezetnek be, amelyek versenyhátrányt okoznak más közlekedési alágazatokkal szemben, illetve az adott vasút kapacitását is csökkenthetik.

\section{A VÁGÁNYGEOMETRIA MÉRÉSI MÓDSZEREI}

A cikk fő céljának a terhelt pályaalak felvételét, vagyis a sínszálak - mint szabálytalan térgörbék - helyzetének mérését, leírását tekinti az átgördülő jármü által keltett deformációs viszonyok között egy olyan derékszögű koordináta-rendszerben, ahol az x koordináta-tengely (pálya menti úthossz) párhuzamos az elméleti vágánytengellyel, y koordináta-tengely a vízszintes (irány) és $z$ koordináta-tengely a függőleges (fekszint) síkban helyezkedik el. A gyakorlatban általában $\mathrm{x}$ függvényében ke- ressük az egyes sínszálak y és z koordinátáit. A mindenkori vágánygeometriai hibák felkutatására irányuló vizsgálatok főbb módszerei a következők:
a. szemrevételezés;
b. geodéziai felmérés;
c. vonalbeutazás;
d. jármüdinamikai mérés;
e. inerciális elvü mérés;
f. húrelvü mérés.

a. A szemrevételezéses vizsgálat szerepét nem szabad lebecsülni, a vasúti diagnosztika sok területén a legfontosabb módszerek közé tartozik. Az emberi ítélőképesség bonyolultabb összefüggések felismerésére képes, mint bármely korszerű mérőrendszer vagy számítógép. Azonban a vágánygeometriai vizsgálat tárgyát képező, jellemzően milliméteres-centiméteres nagyságrendü, gyakran csak a vonatáthaladás alatti deformációk észlelése emberi szemmel nem lehetséges.

b. A geodéziai felmérés kifejezetten alkalmas ugyan a sínszálak (mint időben állandó térgörbék) nagy pontosságú felvételére, ám a módszer nem termelékeny, és nehézségeket okoz a terhelt pályaalak bemérése. Ezért elsősorban a vágányépítés során és a vágányszabályozás előkészítésére alkalmazzák.

c. A vonalbeutazás alatt a pályafenntartási szakemberek azon tevékenységét értjük, amikor a vasúti járművön utazva annak szabálytalan mozgásairól - amelyeket veszélyesnek ítélnek - feljegyzéseket készítenek. Ilyen vonalbeutazások az érvényes elöírások szerint rendszeresen megtörténnek.

d. A jármüdinamikai mérések során a vágánygeometriai hibákon áthaladó mérőkocsiban mérhető gyorsulásokból és erőkből következtethetünk a vágány állapotára. A vonalbeutazásban és jármüdinamikai vizsgálatban közös, hogy indirekt módon, a pálya-jármü rendszer jármü alrendszerében történő megfigyelések és mérések útján adnak képet a vágánygeometriáról. Magyarországon jármüdinamikai mérörendszernek tekinthető pl. a MÁV Központi 


\section{Vasúti közlekedés}

Felépítményvizsgáló Kft. (MÁV KFV Kft.) 007. sz. felépítményi mérőkocsiján elhelyezett dinamikai mérőrendszer. E diagnosztikai módszer jelentős, mert - bár a vágánygeometriát indirekt módon vizsgálja - közvetlenül meghatározható vele a tényleges veszély, mégpedig a kisiklást (valamint a pálya maradó alakváltozását) előidéző erőrendszer mindenkori állapota. Meg kell említeni azonban, hogy a vonalbeutazások és jármüdinamikai mérések csak az adott, vizsgálathoz használt jármünek az aktuális mérési sebességnél mutatott viselkedéséről adnak képet, tehát nem használhatók általánosan a kisiklási kockázat megítélésére. Figyelemre méltó kísérletek történtek a jármüdinamikai mérési eredményeket és a vágány geometriáját összekapcsoló matematikai modellek megadására [2]. Azonban a vasúti pálya-jármü rendszer viselkedésének korrekt leírása annak bonyolultsága miatt szinte lehetetlen, ezért ilyen módon a pontos vágánygeometria nem vehető fel. Kijelenthetö, hogy a jármüdinamikai mérés és a vágánygeometria direkt mérése (pl. inerciális vagy húrelven) egymást kiegészítő tevékenységek, és az együttes alkalmazásuk indokolt.

e. Az inerciális elven mérő rendszerek a hosszfekszint- és irányparamétert a jármű haladása során fellépő gyorsulások mérésével határozzák meg. Amennyiben a gyorsulásmérők a kocsiszekrényen helyezkednek el, további szenzorok szükségesek a sínek és a gyorsulásmérő mindenkori relatív helyzetének meghatározásához. A mért gyorsulási adatsorokból a terhelt pályaalak, tehát a sínek térgörbéi kétszeres integrálással elvileg egyértelmüen (azaz a választott hullámhossztartományon belül torzításmentesen) meghatározhatók. A MÁV is alkalmazott korábban ilyen jellegü mérörendszert. A módszer hátránya, hogy a mérés csak akkor értékelhető, ha a mérőkocsi egy adott sebességnél, általában 20-30 km/hnál gyorsabban halad. Ennél kisebb sebesség esetén az értékelendő gyorsulások mértéke annyira kicsivé válik, hogy hasonló nagyságrendü lesz a mérés hibájának nagyságrendjével. Korszerü inerciális mérörendszerek sem képesek mérési eredményt produkálni annak a pályarésznek a környezetében, ahol a vizsgálat során a mérökocsi például egy vörös jelző előtt megáll. Gyorsulásmérők nem csak mérővonatokra szerelhetők fel: nagy menynyiségü hasznos diagnosztikai információ nyerhető a pályafenntartás számára, ha személy- és tehervonatokat továbbító mozdonyok forgóvázára helyezik fel [3]. Inerciális egységeknek tekinthetők a keresztfekszint (túlemelés) mérésére használt giroszkópok, dőlésmérők is, amelyek az alapvetően húrelvü mérörendszerrel felszerelt jármüveknek is általában elengedhetetlen tartozékai (pl. a MÁV KFV Kft. FMK-004-es és FMK-007-es sz. felépítményi mérőkocsijai). A giroszkópok a mérővonat haladási sebességétől függetlenül alkalmazhatók

f. Azért választottam a cikk alaptémájául a hárompontos húrmérés témakörét, mert ezzel a módszerrel történik a hosszfekszint (süppedés) és irány paraméterek mérése a MÁV, a GYSEV és a HÉV vágányain, és ezzel a módszerrel jött létre az a nagy és rendszerezett adathalmaz, amelyre alapozva a kutatási munkám folyik. A módszer hátránya, hogy a mért értékek viszonyítási rendszere a mérőjármü haladása során a jármü elfordulásai és elmozdulásai miatt folyamatosan változik, vagyis például a hosszfekszint mérési grafikonja - további számítások elvégzése nélkül - nem adja meg a pályának a valós (elvi vágánytengelyhez viszonyított) alakját, hanem annak egy jelentősen torzított képét mutatja meg. A torzítás miatt elvileg a periodikusan ismétlődőhibaegyüttesek-hulámhosszuktól és a mérőkocsi húrelrendeződésétől függően - szélsőséges esetekben eltűnhetnek a mérési eredményből, illetve kétszeres amplitúdóval jelenhetnek meg. A különböző húrelrendezésü mérőkocsik mérései nem vethetők össze, mert a pálya képét különbözőképp torzítják. Bár a húrelvü mérések önmagukban nem adják meg a pálya valós alakját, az elmúlt évszázadokban sikerrel alkalmazták őket pályafenntartási célokra, és - Magyarországon statisztikai elven mérethatárokat határoztak meg a torzított mérési eredmények értékeléséhez. A húrelvű mérési adatsorok - a számítógépek 


\section{Vasúti közlekedés}

teljesítményének növekedésével és a későbbiekben részletezett torzításmentesítési technikák felfedezésének köszönhetően - az utóbbi évtizedekben alkalmasak lettek a terhelt valós pályaalak meghatározására is. Ösztönzi a valós pályaalak kiszámítását az Európai Unió tagállamaiban és tagjelölt országaiban az EN 13848-as szabványsorozat [4], illetve az ide vonatkozó átjárhatósági müszaki elöírás [5]. A $M A ́ V K F V K f t$. által üzemeltetett mérési rendszerek a kor igényeinek megfelelően torzításmentes hosszfekszint- és iránymérési grafikonok szolgáltatására is képesek az említett szabvány szerinti $D 1$ $(3 m<\lambda \leq 25 m)$ és D2 $(25 m<\lambda \leq 70 m)$ hullámhossztartományon. Az átszámítás néhány másodperces időeltolódással megvalósul, és a torzításmentes mérési grafikonokat a mérővonaton tartózkodó pályafenntartási szakember azonnal megkapja.

A húrmérési eredményből az e cikkben bemutatott módon meghatározhatunk egy olyan pályaalakot, amelyen a húrmérést elvégezve éppen ugyanazt az eredményt kapjuk. A D1 vagy $D 2$ hullámhossz-tartományt reprezentáló adatsor elöállításához használt digitális sáváteresztő szürés azonban eltérést okoz a valós pályaalakhoz képest. Ilyen probléma merül fel például akkor, ha a végtelenül hosszú, hibamentes pályában egyetlen - koszinuszhullámmal reprezentált - lokális hibát veszünk fel [6]. A következőkben a húrelvü mérés matematikai modelljét, majd a torzításmentessé tétel általánosan használt módszerét mutatom be, különös tekintettel a hibamentes pályán jelentkező izolált, koszinusz alakú pályahiba méréssel történő rekonstruálhatóságára.

\section{A HÚRMÉRÉSI GRAFIKON ÉS ANNAK TORZIITÁSMENTESSÉ TÉTELE}

A magyarországi vágánymérő kocsikon a hárompontos húrmérés elvén történik a pálya torzított alakjának felvétele. A mérővonat a $p(x)$ pályafüggvény $\left(x_{M}-a\right)$ és $\left(x_{M}+b\right)$ abszciszszájú pontjai között minden pillanatban $L$ hosszúságú virtuális húrt feszít ki (1. ábra), amelynek tényleges hossza és vízszintes vetü- leti hossza azonosnak tekinthető. Az $M$ mérési pont a virtuális húrt $a$ és $b$ hosszúságú részre osztja. A mérés mindenkori eredménye a pálya $P$ pontjának és a húr $M$ pontjának e-vel jelölt pillanatnyi távolsága. A mérési eredményekből álló $e(x)$ függvény (a torzított mérési regisztrátum) a következőképp írható fel:

$$
e\left(x_{P}\right)=p\left(x_{P}\right)-\frac{b}{L} p\left(x_{P}-a\right)-\frac{a}{L} p\left(x_{P}+b\right)
$$

\section{1. ábra: Hárompontos húrmérés elve}

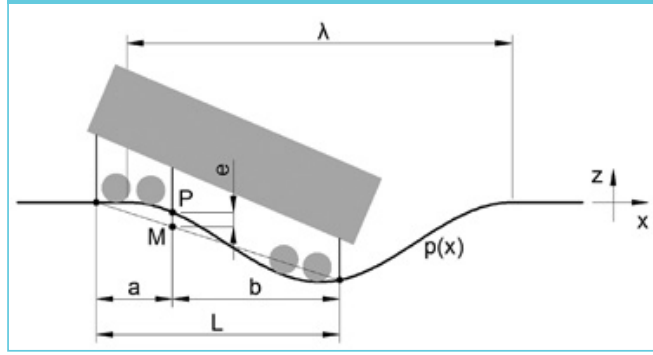

Cél a mérés torzításmentessé tétele, vagyis az $e(x)$ torzított mérési regisztrátumból $p(x)$ valós pályaalakot szeretnénk megkapni. Megjegyzendő, hogy a torzításmentesítésre több matematikai megoldás kínálkozik, például a nagy méretü, (1) típusú egyenletekből álló, határozatlan lineáris egyenletrendszerek optimális megoldásával operáló eljárás [7], azonban ezt nem tárgyalom, hanem a gyakorlatban általánosan elterjedt módszert mutatom be.

A fent definiált (1) vágánymérési tevékenységet lineáris időinvariáns (LTI) rendszernek tekinthetjük, amelyben a $p(x)$ bemeneti jelre érkező válaszjel $e(x)$. Ismert, hogy az ilyen rendszerek egyértelmüen jellemezhetök az egységimpulzusra adott válaszukkal, amit a továbbiakban h-val jelölök.

Amennyiben a $h$ függvényt fel tudjuk írni, a rendszer teljes müködése ismertté válik, vagyis lehetséges lesz a kimenet (torzított mérési regisztrátum) alapján a bemenet (valós pályaalak) rekonstruálása [8]. Az egységimpulzus jelen esetben egy képzeletbeli, egységnyi magasságú és zéró hosszúságú, tüske alakú vágánygeometriai hiba ( $2 a$ ábra), a rendszer válasza pedig az e hibán áthaladó mérőkocsi által felrajzolandó 


\section{Vasúti közlekedés}

\section{2. ábra: Lokális hibák és torzított, ill. torzításmentesített képuik}

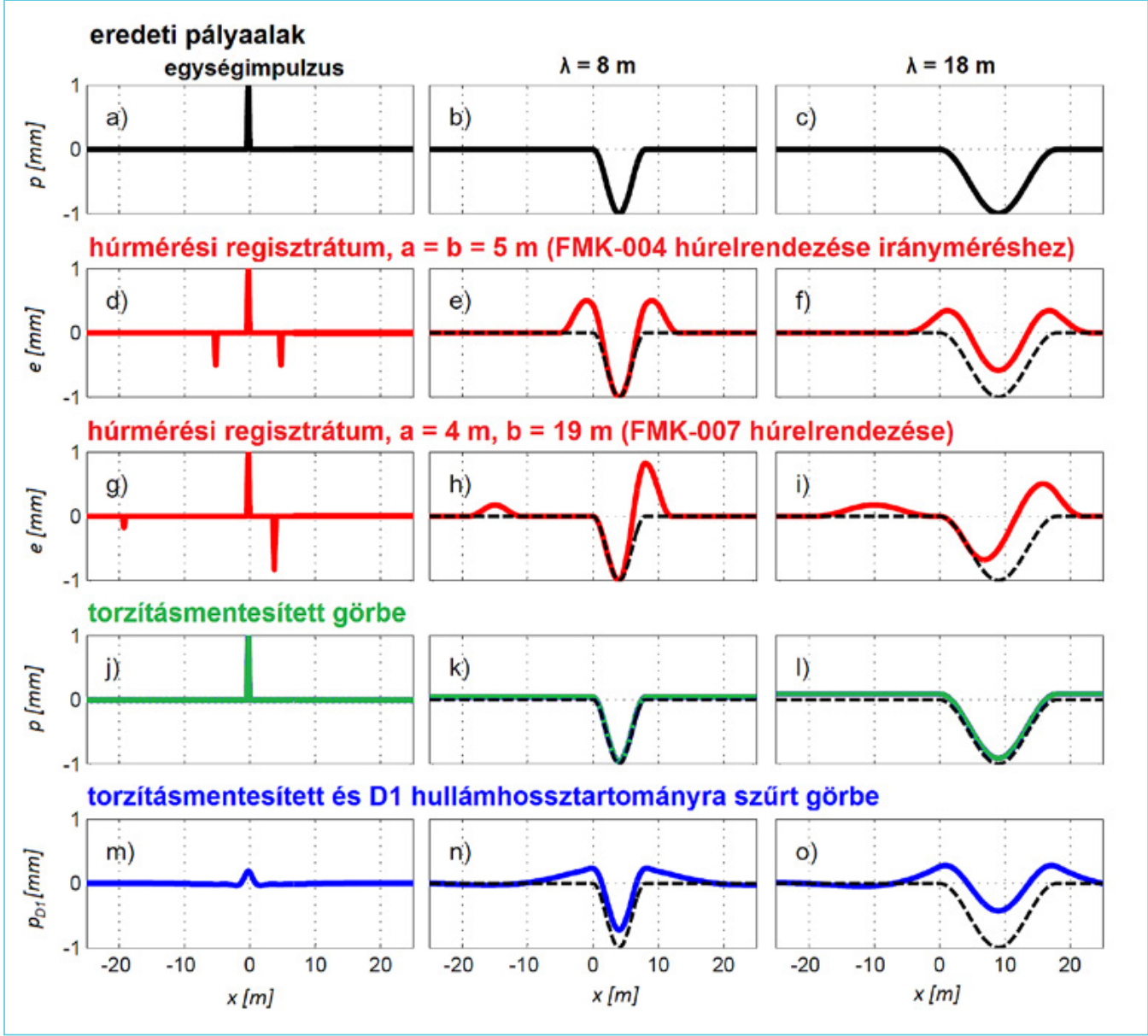

mérési regisztrátum, amelyben értelemszerüen két további, ellentétes irányú tüske is megjelenik. Ez a $h$ válaszjel csak a húr tulajdonságaitól függ, ezért (1) segítségével könnyen elöállítható például az FMK-004 mérőkocsi (irány paraméter felvételéhez használt) $a=5 m, b=5 m$ húrelrendezésére ( $2 d$ ábra), valamint az FMK-007 mérőkocsi $a=4 m, b=19 m$ húrelrendezésére ( $2 g$ ábra). A $h$ függvény segítségével a rendszer könynyen modellezhető. A húrmérés során képződő torzított regisztrátum nem más, mint a pályafüggvény és a mérőhúr méreteitől függő $h$ függvény konvolúciója:

$$
e(x)=(p * h)(x)=\int_{\xi=-\infty}^{+\infty} p(\xi) h(x-\xi) d \xi .
$$

A gyakorlatban kihasználjuk azt a tulajdonságot, hogy két függvény konvolúciója megegyezik Fourier-transzformáltjaik szorzatával. A Fourier-transzformáció a függvényt vagy jelsorozatot esetünkben $\mathrm{x}$ „úttartományból” „út menti frekvenciatartományba”, illetve a $\lambda$ „hullámhosszak tartományába”, viszi át. Vagyis a vágánymérőkocsin zajló húrmérés az alábbi egyszerü módon is leírható:

$$
\hat{e}(\lambda)=\hat{p}(\lambda) \hat{h}(\lambda),
$$

amely egyenértékü az (1) egyenlettel, és ahol $\hat{e}$, $\hat{p}$ és $\hat{h}$ jelölik rendre $e, p$ és $h$ Fourier-transzformáltjait. Felmerülhet a kérdés, hogy a (2) 


\section{Vasúti közlekedés}

szerinti egyszerű konvolúció végrehajtásával szemben miért előnyösebb a Fourier-transzformáltak számítása és (3) szerinti művelet elvégzése. A válasz a számítógépes müveletigényben keresendő: az utóbbi eljárás jelentősen gyorsabb [9].

A $h \hat{~ k o m p l e x ~ e ́ r t e ́ k u ̉ ~ f u ̈ g g v e ́ n y, ~ a m i t ~ a ~ h a-~}$ zai szakirodalomban átviteli karakterisztikának neveznek. Szemléletessé tehetjük, ha abszolútértékét, illetve irányszögét ábrázoljuk a hullámhossz függvényében, ezek ugyanis éppen a szakmai körökben közismert amplitúdókarakterisztika-függvényt és fáziskarakterisztika-függvényt adják meg. Az átviteli karakterisztika zárt képlettel is megadható [10]. A fentiek alapján a pályafüggvény dekonvolúcióval (a konvolúció ellentett müveletével) nyerhető, ami a Fourier-transzformáltakon $\hat{\mathrm{h}}$-val való osztást jelent, vagyis

$$
\hat{p}(\lambda)=\frac{\hat{e}(\lambda)}{\hat{h}(\lambda)} .
$$

A $p(x)$ függvényt $p^{\wedge}(\lambda)$ függvényből inverzFourier-transzformációval kaphatjuk meg. $\mathrm{Az}$ ilyen módon meghatározott $p$ alkalmas arra, hogy kiszámítsuk a pálya torzított képét tetszőleges húrelrendezés feltételezésével, ehhez (1)-(3) összefüggések valamelyikét lehet alkalmazni. Ez azt jelenti, hogy adott húrelrendezéssel felvett torzított mérési eredmény könnyen átszámítható egy másik, adott húrelrendezésnek megfelelö mérési eredménnyé.

Adott pályaszakasz húrmérése (3) egyértelmű eredményt ad, azonban ez fordítva nem igaz: adott húrmérési eredményből általános esetben nem állítható elö egyértelmüen az azt létrehozó pályaalak, vagyis csak feltételezett pályaalakot határozhatunk meg: egy adott húrmérési eredményt elvileg többféle pályaalak generálhatja. Ennek matematikai reprezentációja, hogy zérussal nem lehet osztani, így (4) függvény $\hat{h}(\lambda)=0$ esetén nem értelmezett. Fontos megemlíteni, hogy az amplitúdókarakterisztika-függvénynek $a$ és $b$ közös osztóinál zérushelyei vannak, amelyek számítási nehézségeket okoznak a további műveletek során, azonban gyakorlati problémát nem jelentenek. Egyes hazai szakirodalmakban tévesen szere- pel, hogy kizárólag szimmetrikus húrelrendezés esetén léteznek ilyen zérushelyek : 4+19 méteres húr esetén például a $\lambda_{0}$ zérushelyek 4 és 19 közös osztóinál vannak: $\lambda_{0}=1 \mathrm{~m} ; 0,5 \mathrm{~m}$; 0,333 m; 0,25 m... (5. ábra kék görbéje).

A (4) képlet alapján számított grafikon önmagában több okból sem használatos a gyakorlatban. Egyrészt az íves, átmenetiíves vagy magassági lekerekítésben fekvő pályaszakaszok esetén nem az eredeti pályaalakot adná. Ennek magyarázata, hogy ilyen esetekben a torzításmentesített képben lehetetlen elválasztani a tervezett vonalvezetési elemeket (ívek, magassági lekerekítések) a vágánygeometriai hibáktól, ezért azok nagy amplitúdójú és nagy hullámhosszú vágánygeometriai hibákként jelentkeznek. Másfelől megközelítve a problémát: egy térképre berajzolható, íveket tartalmazó nyomvonal nem ábrázolható alakhelyesen egy derékszögü koordináta-rendszerben egy függvényként. További probléma a torzításmentes, de szüretlen képpel, hogy az igen kis hullámhosszú összetevők és az igen nagy hullámhosszú összetevők a húrmérés során bizonytalanul érzékelhetők, és ezekben a hullámhossz-tartományokban a mérési pontatlanság a torzításmentesített képben felerősödve jelentkezne. Hozzáteszem, hogy az eredeti húrmérési grafikon ábrázolása és feldolgozása esetén is szokás az irány paraméter esetén a helyszínrajzi ívek és átenetiívek zavaró hatásának eltávolítása: az FMK-004 és FMK-007 mérőkocsik esetében erre egy 40 méteres bázisú mozgóátlagoló eljárás szolgál.

A fentiek miatt a vágány geometriájának diagnosztikai célú, közvetlenül alkalmazható, torzításmentes leírása során a tervezett helyszínrajzi és magassági vonalvezetési elemek alacsony frekvenciás hatását, illetve a diszkrét mintavételezés miatt már nem értékelhető nagy frekvenciájú jeleket el kell távolítani. Ez a jelenlegi európai gyakorlatban sáváteresztő szürővel valósul meg. Megjegyzendő, hogy a hárompontos húrral mérő rendszerek esetén a húrelrendezést úgy célszerű megválasztani, hogy a leszürt hullámhossztartományba ne essen zérushely, vagyis $a$ és $b$ húrméretek legnagyobb közös osztója kisebb legyen a 


\section{Vasúti közlekedés}

vizsgálandó legkisebb pályahullámhossznál. A szürést is célszerü a Fourier-transzformált segítségével elvégezni. Az alábbi képlettel a torzításmentessé tett és sávszürt pályafüggvény $\left(p_{D}\right)$ Fourier-transzformáltját adjuk meg:

$$
\hat{p}_{D}(\lambda)=\frac{\hat{e}(\lambda)}{\hat{h}(\lambda)} W_{D}(\lambda),
$$

ahol $W_{D}$ az elöírt hullámhossztartományra történő sávszüréshez szükséges függvény, amely minden $\lambda$ hullámhossz-összetevőhöz megadja, hogy milyen mértékben kerüljön be a végső regisztrátumba. A $p_{D}$ függvényt $\hat{p}_{D}$ függvényből inverz-Fourier-transzformációval kaphatjuk meg.

A valóságban a mérési eredményeket diszkrét pontokban vesszük fel: a mai magyar gyakorlatban $\Delta x=0,25 \mathrm{~m}$ felbontású ekvidisztáns mintavételezés történik a mérendő pályaszakaszon. A torzításmentessé tételhez a teljes mérőmenet során meghatározott e diszkrét értékeit tartalmazó hosszú jelsorozatból alkalmas elemszámú, részben átfedö jelsorozatokat veszünk ki, amelyekből a vizsgálandó $D 1$ vagy D2 jelü hullámhossztartomány leszürhető. Ehhez a hullámhossztartományt reprezentáló legnagyobb hullámhossz többszörösének megfelelő hosszúságú jelsorozat alkalmazása szükséges. A kivett jelsorozatokon a mérővonatok szoftverei elvégzik a diszkrét Fourier-transzformációt (gyors Fourier-transzformációval), illetve végrehajtják az (5)-nek megfelelő diszkrét müveletet. Közben gondoskodnak az így létrejövő átszámított jelsorozatok összeillesztéséről a teljes mérési fájlban a megfelelő átlapolási megoldással.

\section{ELSZIGETELT LOKÁLIS HIBÁK VISELKEDÉSE A TORZÍTÁSMEN- TESSÉ TÉTEL ÉS SÁVSZÜRÉS HATÁSÁRA}

Amint arról korábban szó volt, bár a torzításmentessé tétel elvileg önmagában képes megadni a valós pályaalakot, azonban az elözőekben részletezett $D 1$ vagy $D 2$ hullámtartományra történő szürés hatására más jellegü torzulások lépnek fel. Tegyük fel, hogy a pálya valós $p$ alakja a következőképp írható le:

$$
p(x)=\left\{\begin{array}{cl}
0 & , \text { ha } x<0 \\
\cos \left(\frac{2 \pi}{\lambda} x\right)-1, & \text { ha } 0 \leq x \leq \lambda \\
0 & , \text { ha } \lambda<x
\end{array}\right.
$$

E pályaalak megfelel a hézagnélküli pályák kivetődésbiztonsága szempontjából fontos „A” típusú izolált irányhibának (vizsgálataimban mindegy, hogy irány vagy hosszfekszint paraméterről van szó). Két, különböző pályahibán keresztül szemléltetem az Octave, ill. Matlab programokban végzett számításaim eredményét. Az alkalmazott ablakhossz $100 \mathrm{~m}$, ami 400 mérési pontot jelent. Az első koszinusz alakú hiba $\lambda$ hullámhossza $8 \mathrm{~m}$ ( $2 b$ ábra), a másodiké $18 \mathrm{~m}$ (2c ábra). Elvégezve rajtuk az (1) vagy (2) vagy (3) szerinti húrmérést az FMK-004 és FMK-007 mérővonatok húrelrendezésének megfelelően, a $2 e, 2 f, 2 h$ és $2 i$ ábrákon látható regisztrátumokat kaptam. A torzításmentessé tevő eljárással (4) az előbb említett, piros színnel jelölt függvényekből számított $p$ pályafüggvényeket a $2 k$ és $2 l$ ábrák mutatják be. Az eredmény - a Fourier-transzformáció ablakhosszától függő kis eltolódással - megfelel az eredeti pályaalaknak, függetlenül a húrelrendezéstől. A torzításmentessé tévő eljárás után a $D 1$ hullámhossztartományra történő szürést is megvalósítottam (5) mindkét húrelrendezés esetében, és a $2 n$ és $2 o$ ábrákon látható függvényeket kaptam. A $W_{D 1}$ alkalmazott értékeit a prEN 13848-1:2016 számú elözetes szabvány C.1 táblázatának megfelelően választottam meg (3. ábra). Ilyen esetben tehát a valós pályaalaktól jelentősen eltérő eredmény jöhet létre, ami félreértést okozhat a kiértékelés során, pedig a vizsgált pályahiba hullámhossza beleesik a vizsgált $3 . . .25 \mathrm{~m}$ közötti tartományba. „Alapvonaltól csúcsig” típusú kiértékelés esetén a valódi hibaamplitúdónak $\lambda=8 m$ esetén a $72 \%$-át ( $2 n$ ábra), $\lambda=18 \mathrm{~m}$ esetén a $43 \%$-át (2o ábra) kaptam. Megvizsgáltam, hogy „csúcstól csúcsig” kiértékelés mennyiben tükrözné a valódi hibaméretet. A tapasztalatom az, hogy $3 m \leq \lambda \leq 11 m$ hullámhosszúságú hibák esetén $p_{D 1}$ grafikon minimuma és maximuma közti különbség meghaladja a valós hibanagyság $90 \%$-át, azonban $\lambda=18 m$ esetén ( $2 o$ ábra) ez az érték már csak $71 \%$. Érdemes megfigyelni az egységimpulzus- 


\section{Vasúti közlekedés}

függvény tökéletesen torzításmentessé tehető tulajdonságát (2j ábra). A szürő müködése megfigyelhető a $2 m$ ábrán: mivel az egységimpulzus-függvény hullámhossza zéró (kívül esik a D1-es hullámtartományon), a szürés igyekszik elnyomni a jel amplitúdóját.

\section{3. ábra: Sáváteresztő szûrő a $D 1$ hullám- tartományhoz}

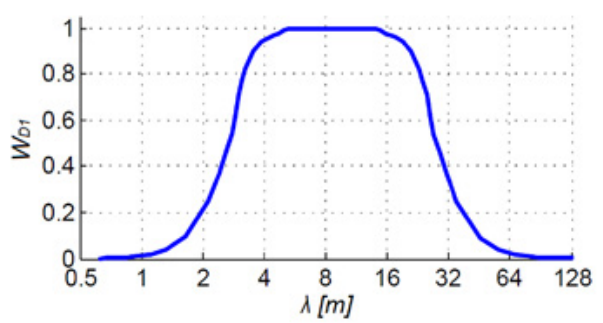

A 4. ábrán az FMK-007 jelü mérővonat eredeti húrelrendezésével felvett iránymérési grafikonjának egy 150 méteres darabját vörös színnel jelenítettem meg. A bemutatott szakasz $90 \mathrm{~km} / \mathrm{h}$ sebességgel járható hézagnélküli vágányban, $500 \mathrm{~m}$ sugarú tiszta ívben található. A pályaívből származó konstans húrmagasságértéket nem vettem figyelembe az ábrázolásnál. A bemutatott pályarészen a méréskor egy kb. $12 \mathrm{~m}$ hosszú, „A” típusú kritikus irányhiba volt, ami az azt követő napokban jelentősen súlyosbodott és balesetveszélyessé vált. A sávszűrés nélkül számított torzításmentes pályaalakot zöld színnel rajzoltam fel. Feltételezhető, hogy a vágány irányviszonyait ez a görbe alakhüen mutatja be. (A felhasznált ablakhossz $150 \mathrm{~m}$ volt.) A torzításmentés után D1 hullámtartományra szürt adatsort kék színü görbe reprezentálja. Látható, hogy ez utóbbi adatsor „alapvonaltól csúcsig" típusú kiértékelése esetén a valóságosnál kisebb értéket kapunk. A fentiek alapján azt javaslom, hogy olyan határértékeket célszerü alkalmazni Magyarországon a D1-es adatsorokra, amelyek garantálják, hogy a példában szereplőhöz hasonló kritikus irányhibáknál azonnali beavatkozás történjen.

\section{LOKÁLIS HIBA TORZÍTOTTSÁ- GÁNAK MÉRTÉKE A HÚRMÉRÉ- SI REGISZTRÁTUMBAN}

A vázolt probléma megoldása felé vezető utakat keresve részletesen megvizsgáltam a $p(x)$ alakú pályarészek húrmérési képének matematikai leírási lehetőségeit. A (6) pályafüggvényt (1) egyenletbe helyettesítve analitikus úton levezettem a mindenkori torzított pályaalakot megadó függvényeket. Arra jutottam, hogy a torzított $e(x)$ mérési grafikon ebben az esetben hétféle $f(p(x))$ hozzárendelési szabállyal

\section{4. ábra: Vágánykivetődéssel fenyegető irányhiba és mérési grafikonjai}

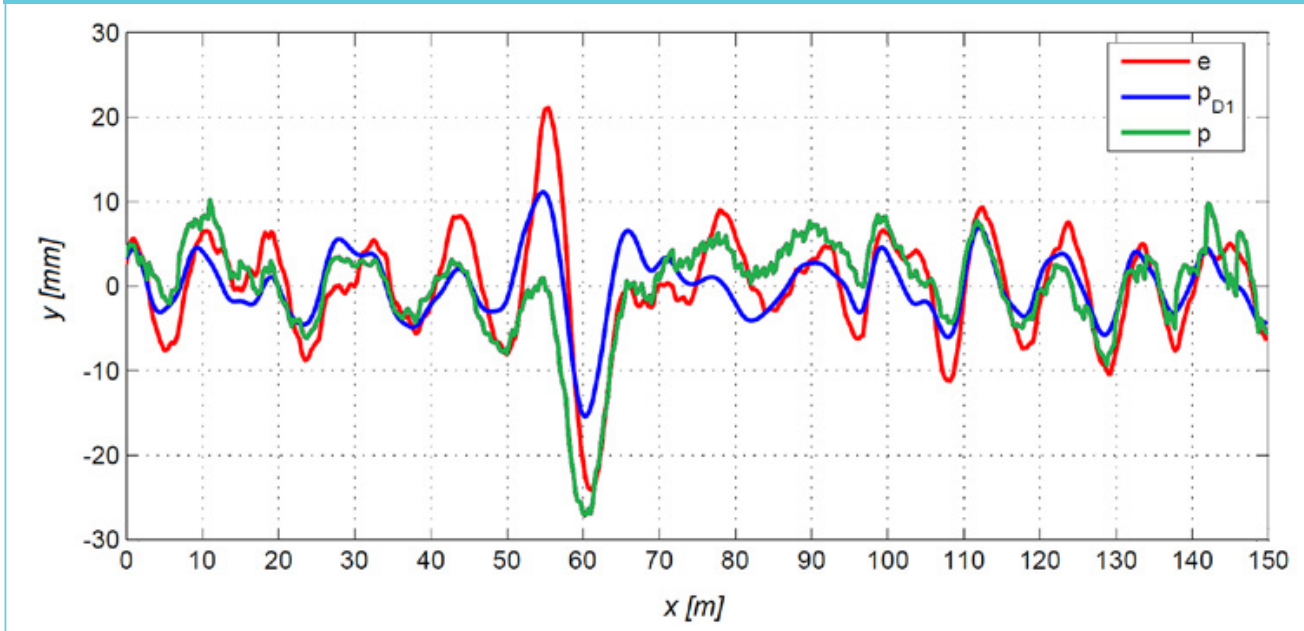




\section{Vasúti közlekedés}

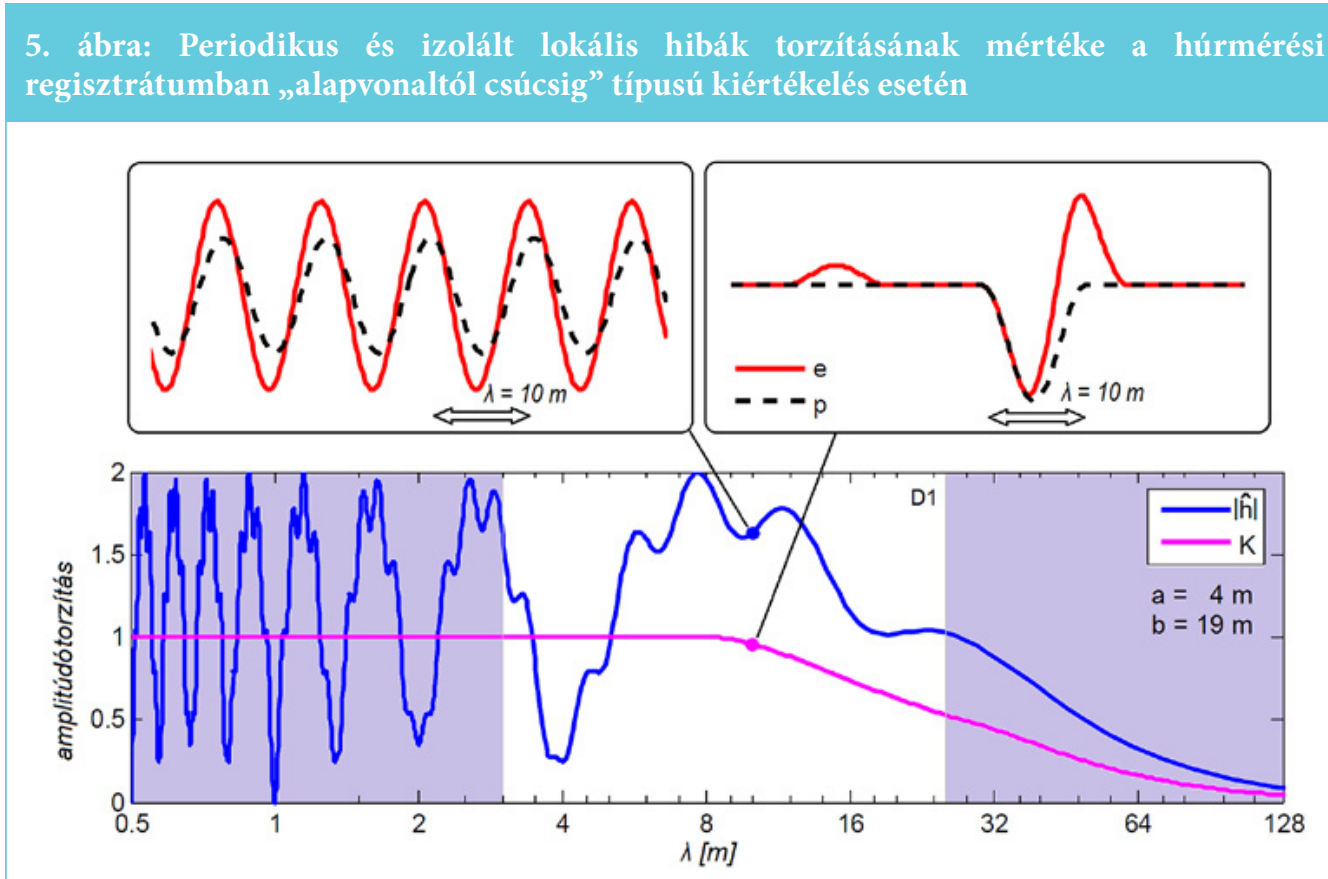

írható le. Az egyes hozzárendelési szabályok alkalmazhatósága attól függ, hogy a húrvégeket és a mérési keresztmetszetet meghatározó három pont közül éppen melyek tartózkodnak a koszinuszhullámon, illetve előtte és utána. A hosszadalmas levezetés közlésére terjedelmi korlátok miatt nem kerül sor. Meghatároztam az ilyen (6) alakú elszigetelt pályahibákra vonatkozó amplitúdótorzítási függvényeket, amelyek megadják, hogy a húrmérés során felvett torzított mérési regisztrátum szélsőértéke hányszorosa a valós pályafüggvény szélsőértékének. Meghatároztam tehát a $2 e, 2 f, 2 h$ és $2 i$ ábrákon felrajzolt piros és fekete görbék minimumértékének $K$ arányát $\lambda$ hibahullámhossz függvényében analitikus úton.

Legyen $a \leq b$. A három intervallumon három hozzárendelési szabály érvényes:

I. ha $\lambda \leq 2 \mathrm{a}$, akkor a torzított kép negatív szélsőértéke megegyezik a valós pályahibanagysággal (lásd: $2 e$ és $2 h$ ábrák):

$K \equiv 1$,

II. ha $2 a \leq \lambda \leq \lambda_{c}$ (ahol $\lambda_{c}$ az a és b függvénye):

$K=\frac{\sqrt{1+\frac{b^{2}}{L^{2}}-\frac{2 b}{L} \cos \left(\frac{2 \pi}{\lambda} a\right)}+1-\frac{b}{L}}{2}$,

III. ha $\lambda_{\mathrm{C}} \leq \lambda$ :

$K=\frac{\sqrt{Q^{2}+R^{2}}}{2}$,

ahol

$$
\begin{aligned}
& Q=1-\frac{a}{L} \cos \left(\frac{2 \pi}{\lambda} b\right)-\frac{b}{L} \cos \left(\frac{2 \pi}{\lambda} a\right), \\
& R=\frac{b}{L} \sin \left(\frac{2 \pi}{\lambda} a\right)-\frac{a}{L} \sin \left(\frac{2 \pi}{\lambda} b\right) .
\end{aligned}
$$

A három függvénydarab differenciálható módon csatlakozik egymáshoz. A $K(\lambda)$ függvényt $a=4 m, b=19 m$ behelyettesítésével $\left(\lambda_{c}=29,28 \mathrm{~m}\right)$ az 5 . ábrán bíbor színü vonallal jelöltem. $K$ értéke $\lambda=8 \mathrm{~m}$ esetén 1 , ez a $2 h$ ábrán látható állapotnak felel meg, vagyis a húrmérési grafikon negatív minimuma egybeesik a pályáéval. $K$ értéke az 5. ábrán jelölt $\lambda=10 \mathrm{~m}$ esetén 0,96 , vagyis a húrmérési függvény minimuma majdnem a valós pályafüggvény minimumánál van. $\lambda=18 m$ esetén $K=0,68$ : ez a $2 i$ ábrán látható állapotnak felel meg, vagyis a húrmérési 


\section{Vasúti közlekedés}

grafikon a pályahiba nagyságát kb. 2/3-ára torzította. Az összehasonlítás kedvéért az 5. ábrán $K(\lambda)$ függvénnyel együtt $|\hat{h}(\lambda)|$ függvény is látható, amely a harmonikus (periodikus szinuszos) pályahibák esetén adja meg az amplitúdótorzítás mértékét. A D1 hullámhossztartományt a diagramon eltérő háttérszín emeli ki. Láthatjuk, hogy periodikus hibasorozat esetén a húrmérési grafikon nagyobb kitéréseket tartalmazhat $(\lambda=10 \mathrm{~m}$ esetén $164 \%)$, mint a valós amplitúdó, ám elszigetelt lokális hiba esetén a húrmérési grafikon sosem mutat nagyobb amplitúdót a valóságosnál.

\section{7. ÖSSZEGZÉS}

Az európai előírások szerint a vágánygeometriai mérésnek az irányra és hosszfekszintre vonatkozó grafikonjait torzításmentesen és adott hullámhossz-tartományra szürve kell szolgáltatni. Ezáltal különböző húrelrendezésű mérővonatok mérési eredményei összevethetővé válnak egymással, valamint inerciális mérőrendszer segítségével felvett eredményekkel. Amenynyiben a torzításmentesítési eljárás bemenő adata, a húrmérési regisztrátum stacionárius jelnek tekinthető (irány esetében például helyszínrajzi egyenesről vagy tiszta ívröl van szó), akkor a torzításmentesített, teljes hullámhosszspektrumot tartalmazó grafikon a pálya alakhü, terhelés alatti képét ábrázolja. Ez a grafikon önmagában nemhasználatos, mivel íves pályarészek esetén nem az eredeti pályalakot adja viszsza, illetve a bizonytalanul mérhető igen kicsi és igen nagy hullámhossz-összetevők hatását kedvezőtlenül felerősítheti. A torzításmentes grafikon adott hullámtartományra történő szürésével a pályának ismét egyfajta torzított képe áll elő. A magyarországi gyakorlatra lefordítva mindez azt jelenti, hogy bár az FMK-004 és FMK-007 mérőkocsik húrelrendezése eltérő, a torzításmentesített és D1 hullámtartományra szürt mérési eredményük elvileg azonos, és összevethető bármely más, EN 13848 szabvány szerint működő európai mérőkocsi eredményével. Az eltérések az egyes mérőkocsik terhelési viszonyaitól függnek, vagyis hogy a mérőjármü áthaladásának hatására a pálya milyen mértékben deformálódik. A szakmai szóhasználatban egyszerüen D1-esnek nevezett grafikonok a hagyományos húrmérésre jellemző torzítást tehát nem tartalmazzák, viszont nem tekinthetők a pálya alakhű képének. Kivetődésbiztonság szempontjából kritikus koszinusz alakú izolált pályahibákat vizsgáltam meg, és arra jutottam, hogy a geometriai eltérés milliméterben vett maximumértéke 3-11 m közti hullámhosszaknál a D1-es grafikon szomszédos lokális szélsőértékeinek különbségével („csúcstól csúcsig” típusú kiértékelés) becsülhető. Ezért a D1-es iránymérési grafikon kiértékelésénél fokozott figyelmet kell fordítani a „csúcstól csúcsig” típusú kiértékelésre.

A torzításmentesítési eljárás a húrelrendezésre jellemző átviteli karakterisztikán alapszik. Szimmetrikus és aszimmetrikus húrelrendezés esetén is megjelennek zérusok az amplitúdó-karakterisztikában, amelyek numerikus problémákat okoznak a dekonvolúció során. A szakirodalomban megtalálható hagyományos amplitúdókarakterisztika-függvény csak periodikusan hullámzó hosszfekszint vagy irány esetén adja meg a húrmérési regisztrátum elvi torzítását. Az ilyen amplitúdókarakterisztika nem alkalmas a koszinusz alakú izolált pályahibák „alapvonaltól csúcsig” eljárással figyelembe vett torzításának jellemzésére. Erre a bemutatott (7) - (9) függvények kombinációja alkalmas. Az előbbiekben említett izolált koszinusz alakú irányhiba esetén a húrmérési regisztrátum lokális szélsőértéke és a nullvonal különbsége - egy húrelrendezéstől függő határhullámhossz alatt - pontosan megegyezik a kinyomódás nagyságával. Ha a hiba hullámhossza ennél nagyobb, a húrmérési grafikon a valósnál kisebb kitérést mutat. Torzításos húrmérési grafikon esetében tehát az „alapvonaltól csúcsig” típusú kiértékelésnek kell előtérbe kerülnie az alacsonyabb hibahullámhosszaknál. Ez a hazai mérőkocsik példáján értelmezve azt jelenti, hogy a FMK-004 esetében 5 méternél, FMK-007 esetén 4 méternél kisebb hosszúságú izolált geometriai hiba nagysága a húrmérési grafikonról közvetlenül leolvasható.

Megemlítem, hogy egy adott húrelrendezésű mérőkocsival felvett mérési eredmény átszámítható bármely másik húrelrendezésnek megfelelő mérési eredménnyé. Ez a módszer elvi lehetőséget ad például arra, hogy az ívszabályozások előkészítése során végzendő kézi húrmérést valamely mérőkocsi eredményeinek átszámításával helyettesítsük. 


\section{Vasúti közlekedés}

\section{FELHASZNÁLT IRODALOM}

[1] Zobory I.: A vasúti pálya-jármü rendszer dinamikája - mérése - minősítése. Közlekedéstudományi Szemle, 2015:1 (2015) pp. 6-18.

[2] Zhai, W., Wang, K., Cai, C. Fundamentals of vehicle-track coupled dynamics. Vehicle System Dynamics, 47:11 (2009) pp. 13491376 DOI: http://doi.org/fgp7wr

[3] Linder, C., Schenkendorf, R., Lackhove, C.: Prognoseverfahren zur Gleislageabweichung bei Einzelfehlern. Der Eisenbahningenieur, 02/14 (2014), pp. 17-20

[4] MSZ EN 13848 szabványcsalád (Vasúti alkalmazások. Vágány. A vágánygeometria minősége.)

[5] Európai Bizottság 1299/2014/EU rendelete az Európai Unió vasúti rendszerének infrastruktúra alrendszerére vonatkozó átjárhatósági műszaki előírásokról

[6] Haigermoser, A., Luber, B., Rauh, J., Gräfe, G.: Road and track irregularities:

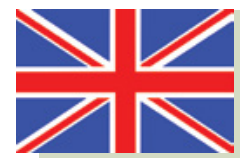

\section{Evaluation of the real amplitude of longitudinal level and align- ment defects based on the results of the chord measurement of track geometry}

Regular monitoring measurements of track geometry guarantee traffic safety. The main methods of measuring track geometry have been reviewed. The paper discusses in detail the principle of the three-point chord survey and its distorted measurement results as well as the generally applied decolouring procedure and the amplitude reduction due to band-pass filtering on the D1 waveband. The functions describing the degree of distortion of the cosine-shaped isolated track defect occurring in the registered data of chord survey were determined by mathematical deduction. It has been found that in the case of isolated local faults, the registered data of the chord survey should not contain any higher amplitude than the real value in the course of the "baseline to peak" evaluation. measurement, assessment and simulation. Vehicle System Dynamics, 53:7 (2015) pp. 878-957 DOI: http://doi.org/gdgxzh

[7] Wang, P., Wang, Y., Tang, H., Gao, M., Xu, J.: Error theory of chord-based measurement system regarding track geometry and improvement by high frequency sampling. Measurement, 115 (2018), pp. 204-216 DOI: http://doi.org/ctb5

[8] Mauer, L.: Determination of Track Irregularities and Stiffness Parameters with Inverse Transfer Functions of Track Recording Vehicles. Vehicle System Dynamics, 24:sup1 (1995), pp. 117-132 DOI: http://doi.org/c2nqzd

[9] Smith, S. W.: The Scientist and Engineer's Guide to Digital Signal Processing. Second Edition. California Technical Publishing, San Diego (1999) pp. 169

[10] Lichtberger, B.: Track compendium. EurailPress, Hamburg (2005) pp. 400-405

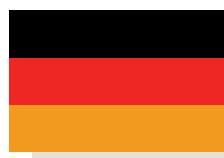

Bewertung der realen Amplituden de Längshöhen- und Richtungsfehler in der Gleisgeometrie aufgrund von Ergebnissen der Sehnenmessung

Regelmäßige Überwachungsmessungen der Gleisgeometrie garantieren die Verkehrssicherheit. Es wurde ein Überblick der wichtigsten Methoden zur Vermessung der Gleisgeometrie gegeben. Der Artikel diskutiert detailliert das Prinzip der Dreipunkte-Sehnenmessverfahren und seine verzerrten Messergebnisse sowie das allgemein angewandte Verfahren für die Befreiung von Verzerrungen und die Amplitudenreduzierung in Folge der Bandbreitenfilterung im D1-Wellenband. Die Funktionen, die den Grad der Verzerrung des cosinusförmigen isolierten Spurfehlers beschreiben, der in den registrierten Daten der Sehnenmessung auftritt, wurden durch mathematische Folgerungen bestimmt. Es hat sich gezeigt, dass bei vereinzelten lokalen Fehlern die registrierten Daten der Sehnenmessung im Verlauf der Auswertung "von Grundlinie zum Spitzenwert" keine Amplitude enthalten dürfen, die grösser ist als der reale Wert. 